
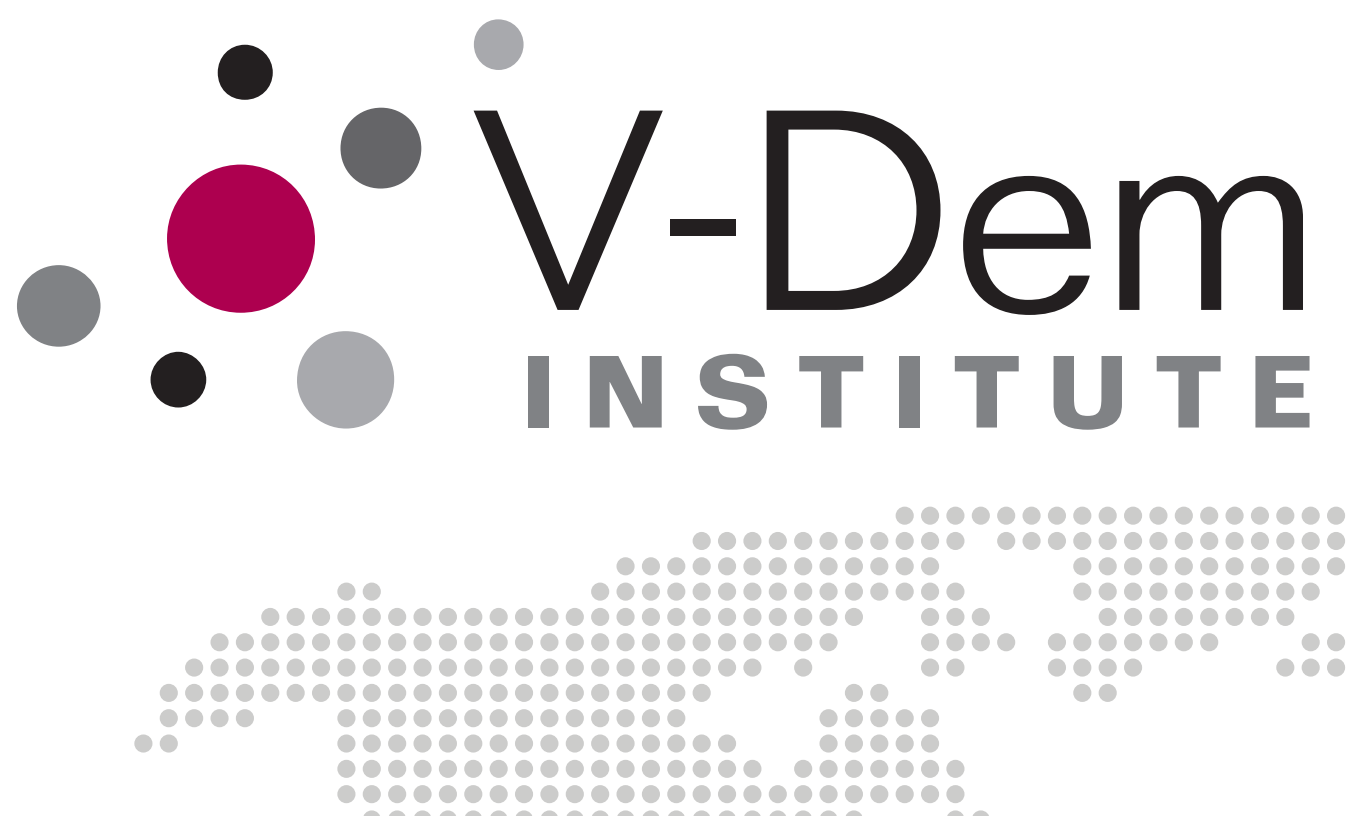

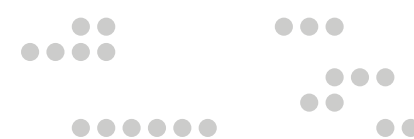

10000000 $00000000 \mathrm{cos}$ $00009009000009000 \mathrm{c}$

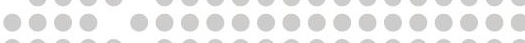

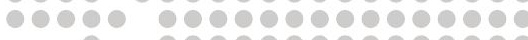
-

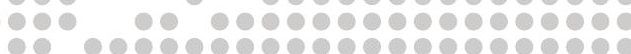

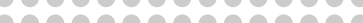

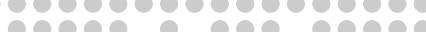
reber

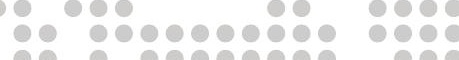

Eroding Regimes: What, Where, and When?

Michael Coppedge

000000000

0000000

000000

100000

10000

000

000

10

10

10

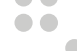

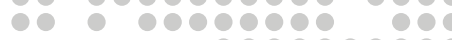

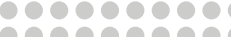

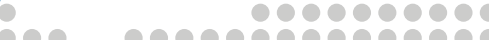

 

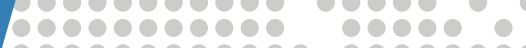

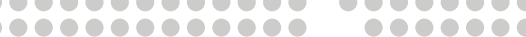

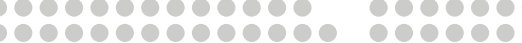

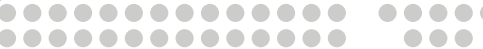

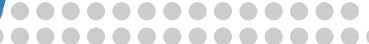
00 rovo0000000000000000 000000000000000000 10000000000000000

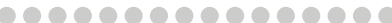

00000000000000

o.

0000000000

00000000000

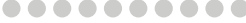

o

-

00000000000

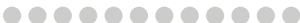

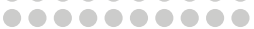

60000000

000000000

0000000

1000000

○०००००

1000

00 
Varieties of Democracy (V-Dem) is a new approach to conceptualization and measurement of democracy. It is co-hosted by the University of Gothenburg and University of Notre Dame. With a V-Dem Institute at University of Gothenburg with almost ten staff, and a project team across the world with four Principal Investigators, fifteen Project Managers (PMs), 30+ Regional Managers, 170 Country Coordinators, Research Assistants, and 2,500 Country Experts, the VDem project is one of the largest ever social science research-oriented data collection programs.

Please address comments and/or queries for information to:

V-Dem Institute

Department of Political Science

University of Gothenburg

Sprängkullsgatan 19, PO Box 711

SE 40530 Gothenburg

Sweden

E-mail: contact@v-dem.net

V-Dem Working Papers are available in electronic format at www.v-dem.net.

Copyright (C) 2017 by authors. All rights reserved. 


\title{
Eroding Regimes: What, Where, and When?*
}

\author{
Michael Coppedge \\ University of Notre Dame \\ Coppedge.1@nd.edu
}

\begin{abstract}
* This paper was originally prepared for presentation at the conference on "Authoritarian Backsliding? Erosion of Democracy in Unlikely Places," Duke University, April 21-22, 2017. This research project was supported by Riksbankens Jubileumsfond, Grant M13-0559:1, PI: Staffan I. Lindberg, V-Dem Institute, University of Gothenburg, Sweden; by Knut and Alice Wallenberg Foundation to Wallenberg Academy Fellow Staffan I. Lindberg, Grant 2013.0166, V-Dem Institute, University of Gothenburg, Sweden; as well as by internal grants from the Vice-Chancellor's office, the Dean of the College of Social Sciences, and the Department of Political Science at University of Gothenburg. We performed simulations and other computational tasks using resources provided by the Notre Dame Center for Research Computing (CRC) through the High Performance Computing section and the Swedish National Infrastructure for Computing (SNIC) at the National Supercomputer Centre in Sweden, SNIC 2016/1-382 and 2017/1-68. We specifically acknowledge the assistance of In-Saeng Suh at CRC and Johan Raber at SNIC in facilitating our use of their respective systems.
\end{abstract}




\section{Abstract}

The political world lately seems to be filled with unexpected erosions of democracy. What is the most useful way to describe these phenomena? Do they all belong to a common syndrome? Certainly there are different degrees of erosion, but are there also different types? How common are such erosions in the world today? Is this a new phenomenon, or are there close parallels with events in the past? If we detect early warning signs of erosion, how concerned should we be that it will continue and culminate in the breakdown of democracy? This paper argues that there are two distinct erosion paths. First, there is a classic path of growing repression of speech, media, assembly, and civil liberties, combined with deteriorating political discourse. The second path involves the concentration of power in the executive at the expense of the courts and the legislature, similar to what Guillermo O’Donnell called "delegative democracy," which entails the erosion of horizontal accountability. Venezuela emerges as the most extreme and most fully articulated instance of erosion along this second path. 


\section{Introduction}

The political world lately seems to be filled with unexpected erosions of democracy. Some of these trends are associated with political figures who have risen to power - Trump, Putin, Chávez, Erdogan, Morales, Orbán, Correa, Kaczynski, Duterte - or were recently in power Thaksin, Berlusconi, Fujimori, the Kirchners - or are getting closer to power - Le Pen, Wilders, Haider, and others. Some of these instances include similar attacks on democratic institutions, especially the media, the courts, and legislatures. And in some cases erosion has gone so far as to constrain civil society organizations and political parties, to threaten the rule of law, to restrict effective suffrage, or to undermine the fairness of elections. Often these erosions, and possible erosions on the horizon, take place in the context of shifting mass attitudes such as extreme partisanship, ideological polarization, intense nationalism, hatred of ethnic minorities or immigrants, admiration of strong leaders, or declining support for democracy. Many of these erosions are unexpected, in the sense that they take place in countries that have been fairly democratic, or at least have held minimally acceptable elections, for a decade or more.

What is the most useful way to describe these phenomena? Do they all belong to a common syndrome? Certainly there are different degrees of erosion, but are there also different types? How common are such erosions in the world today? Is this a new phenomenon, or are there close parallels with events in the past? If we detect early warning signs of erosion, how concerned should we be that it will continue and culminate in the breakdown of democracy?

I find that there are two distinct erosion paths. First, there is a classic path of growing repression of speech, media, assembly, and civil liberties, combined with deteriorating political discourse. There are differences of degree within this type. The most extreme cases preceded the 1973 military coups in Chile and Uruguay, the 1980 coup in Turkey, the 1994 coup in the Gambia, and even conditions leading to Adolf Hitler's appointment as German Chancellor in 1933. This path includes less dramatic backsliding that did not necessarily suspend elections, as in India in 1975, Turkey since 2005, Honduras in 2009, and Bulgaria in 2010-2012. The second path involves the concentration of power in the executive at the expense of the courts and the legislature. It is similar to what Guillermo O'Donnell called "delegative democracy," which entails the erosion of horizontal accountability (O'Donnell 1991). However, I will show that other attributes of democracy also tend to erode as horizontal accountability deteriorates (albeit not as dramatically as on the classic path), which often makes it inaccurate to refer to these delegative cases as "democracies." Venezuela under Chávez and Maduro is by far the fullest realization of this tendency, with fainter echoes in Ecuador, Nicaragua, and Bolivia. It also has 
partial parallels outside Latin America, as in the Thaksin government in Thailand, the Kuchma government in Ukraine, and the Gruevski government in Macedonia. Both paths - more the classic path than the delegative path - slightly increase the risk of a breakdown, defined here as the suspension of elections. But a more powerful and rigorous finding is that the erosion of horizontal accountability tends to increase corruption.

\section{Data, Scope Conditions, and Disaggregation}

Answering the questions of what is going on and which cases are good examples of it is an exercise in both conceptualization and measurement. In this exercise, I avoid the purely deductive extreme of defining a concept in the abstract (and then struggling to measure it) and the purely inductive extreme of finding patterns in data (and then struggling to make conceptual sense of them). Instead, my goal is to develop concepts and measures that are useful in the sense that they simultaneously resonate with the familiar constructs in our minds and are well aligned with the empirical relationships we can observe and measure. The hope is that such concepts and measures will prove to be useful for description and perhaps also for explaining the causes and consequences of different types of erosion of democracy. I therefore proceed by first defining the basic scope conditions implied by a rough version of the concept and choosing the existing index, a measure of liberal democracy, that best captures the property space of interest in a highly aggregated way. Second, I specify thresholds for declines in liberal democracy that do a good job of identifying the prototypical cases (and some others). Third, I disaggregate the index to learn whether the unexpected erosions of democracy tend to follow the same path or different paths. This is what reveals a distinction between diminished rights and freedoms, on the one hand, and diminished horizontal accountability, on the other. Finally, I disaggregate further to show that each path is internally diverse: no two cases of erosion register declines on exactly the same combinations of attributes. From this analysis, Chávez's Venezuela emerges as the most completely developed example of the erosion of horizontal accountability (although it also became much less democratic in other respects).

I offer answers to these questions with Varieties of Democracy (V-Dem) data, which cover most countries from 1900 to the present. Because the V-Dem dataset contains indicators of hundreds of attributes of five conceptions of democracy, it is uniquely suited to the task of pinpointing which aspects of democracy have been eroding and evaluating whether it is more useful to treat them as a single coherent phenomenon, different independent trends, or something that is harder to classify. Most importantly, V-Dem data include some of the most 
valid and reliable indicators of institutions and practices in the realm of the media, courts, legislatures, elections, civil society, and political discourse. ${ }^{1}$

One limitation of V-Dem data is that they exclude public opinion data and therefore cannot address questions about changing mass attitudes. I consider mass attitudes unreliable indicators of how regimes actually perform: they probably track changes over time within countries fairly well (where long attitudinal time-series exist), but survey respondents lack comparative perspective and cannot be expected to give cross-nationally comparable answers. This is not to say that extremism, polarization, intolerance, and low institutional legitimacy are uninteresting. In fact, levels and shifts in such attitudes may serve as early warning signs of regime problems. However, I do not address them in this paper. The V-Dem dataset does include various indicators of deliberative democracy that pick up the quality of elite political discourse. However, while elite discourse may echo public opinion and even help shape it, it is best to treat elite behavior and mass opinion as distinct phenomena.

Defining and measuring the unexpected erosion of democracy depends crucially on scope conditions and the level of aggregation. Implicit in the idea of "unexpected erosions" of democracy is a focus on countries that, first, had already surpassed some minimum threshold of democracy and, second, remained there long enough for electoral politics to be considered normal. I operationalize this by including cases that attained a score on the V-Dem Electoral Democracy Index of at least 0.5 and remained at or above this level for at least eight years before any erosion started. A score of 0.5 is a reasonable threshold for a minimal version of democracy; one that was first met by the United Kingdom in 1911, Spain in 1932, Japan and India in 1952, Chile in 1959, Mexico in 1993, and Tanzania in 2011. Eight years is not a long enough period to ensure that democracy is the only game in town, but it is usually long enough to allow two elected governments to complete their terms. (It is also the longest possible period that allows me to include Russia in the analysis, as its score exceeded 0.5 only in 1992-1999. Given the salience of Vladimir Putin in discussions of the erosion of democracy, it seems important to use a low standard that includes his governments.)

A third scope condition is that the electoral regime continue. Once elections are suspended, we are talking about a breakdown of democracy, not erosion. Whether erosion,

\footnotetext{
1 This draft uses version 6.2 of the data, which covers only a few dozen countries after 2012 . There are likely to be additional cases and somewhat different conclusions in version 7. In addition, the data for 2013-2015 in version 6.2 should be used with care because of attrition among coders in the 2014 and 2015 updates, which created some "jumps" in recent years that are hard to interpret. (If new coders had systematically higher or lower standards than coders who left the study, it is possible that part of the changes in scores around this time reflect that difference rather than a difference in a country's actual level of democracy.) For this reason, my analysis excludes some questionable recent drops in Sweden, Portugal, and Finland. Version 7 uses an improved measurement model that should be less vulnerable to this problem.
} 
however it is defined, helps explain military coups and other events that truncate the electoral regime, is a separate question that I take up briefly below. Here I focus on the erosion of democracy while elections are still on course. I have also made an effort to exclude "erosion" (drops in democracy scores) that happens due to external events, such as occupation by another power. ${ }^{2}$ My analysis therefore excludes occupations of Western European countries by Germany or the allies in the two world wars. ${ }^{3}$ Other invasions such as those by Japan, the United States, or Vietnam have rarely involved countries that met the other scope conditions.

Among countries that meet the scope conditions - countries that had been at least minimal electoral democracies for at least eight years immediately before, that continued to hold elections, and that were not invaded - what kinds of changes constitute "erosion"? My analysis proceeds from the general to the specific. If we define erosion as a drop in the V-Dem Liberal Democracy Index, which is the prefabricated index that is closest to the concept, then there are relatively few cases, it is not clear that they are comparable, and the trends reflect little of the potentially relevant variation. However, the more we disaggregate the concept, the more cases there are that experienced drops on some specific indicators but not others, the clearer it is which of these cases are similar in nature, and the more of the relevant variation they preserve. The Liberal Democracy Index that begins this analysis captures 87 percent of the variance in its two components, electoral democracy and the liberal component; but only 73 percent of the variance in their subcomponents, and only 61 percent of the variance in the most specific indicators used in this analysis. The unexplained variance is potentially useful for describing the erosion pathways more specifically. Disaggregation is the cure for concept-stretching: it provides a more nuanced description of what happened in each case. Disaggregation also makes it possible to analyze whether these instances of erosion are changes on the same dimension or different dimensions.

\section{Drops in Liberal Democracy}

Varieties of Democracy makes available five "high-level" indices to measure different conceptions of democracy: electoral, liberal, participatory, deliberative, and egalitarian. Empirically they are not very different because the electoral democracy index is an important component in the formula for calculating the other four (Coppedge et al. 2016 -IPSR). ${ }^{4}$

\footnotetext{
2 The V-Dem variable v2svinlaut, International sovereignty, does a good job of identifying losses of international sovereignty, which can be defined as a drop in this variable and a negative value after the drop.

${ }^{3}$ I also exclude Finland 1939-45 because Germany and the Soviet Union subjected it to extreme pressures, even though it was not fully occupied and never fell below the 0.5 electoral democracy threshold.

${ }^{4}$ As a result, electoral democracy is correlated with the other indices at .951 to .973.
} 
However, among these indices, liberal democracy is the best single measure of most of the attributes being discussed. The appendix describes this index and the two components, eight sub-components, and 51 indicators that make it up. In addition to electoral democracy, the Liberal Democracy index takes into account legislative constraints on the executive, judicial constraints on the executive, and respect for civil liberties (an index called "equality before the law and individual liberty"). This index should therefore drop when executives weaken legislative oversight, disregard judicial rulings, or undermine judicial independence - all actions that we associate with some of the erosions that motivate this analysis. However, the liberal democracy index is also diluted with other components that probably do not vary much within electoral regimes in the medium term or have little to do with the kinds of erosion that are being discussed today, such as the level of the suffrage, the proportion of officials who are elected, or freedom of movement. It may therefore be sensitive only to the most dramatic changes in the relevant concepts, and may reflect changes that are not relevant to the concept. Furthermore, the liberal democracy index lacks components concerned with "deliberation" (the quality of political discourse among politicians), which I add to the analysis below when examining relationships among components.

Of the 20,274 country-year observations for 173 non-missing countries from 1900 to 2015 that make up version 6.2 of the V-Dem dataset, fifteen percent $(3,089)$ meet the scope conditions. That is, they were minimal electoral democracies for at least eight years, with elections still on course by the end of that year, and without a foreign occupation. However, most of these cases are irrelevant for this analysis because we are interested in declines rather than advances; declines that were not short-term blips, quickly reversed; and declines that exceeded a certain magnitude. Given the overall global trend of increasing democracy, about 2,000 cases did not undergo a net decline in the subsequent five years; about 1,000 did decline. I use five years as the period long enough to exclude ephemeral changes, as it is long enough to encompass one term of most governments. The remaining question is how much of a drop is required to count a decline as a significant "drop" in liberal democracy. It would not be wise to include all drops because there is some measurement uncertainty in V-Dem data. There is measurement uncertainty in all social science data, but V-Dem data have the advantage of including estimates of how much uncertainty there is, in the form of lower and upper bounds for all variables generated by the measurement model or Bayesian factor analysis (Pemstein et al. 2016). ${ }^{5}$ For the Liberal Democracy Index, 68 percent of the true scores should be (on average;

\footnotetext{
5 More precisely, the lower and upper bounds are calculated from Monte Carlo simulation of the distribution of possible true index values. They represent 68 percent highest posterior densities and are therefore comparable to \pm one standard error.
} 
the bounds vary by country-year) within \pm 0.0294 of the median. For this index, I use a drop of .09 or more (on a 0 to 1 scale), which is approximately equivalent to a drop of three standard errors. Subjectively, this threshold selects relevant cases better than large drops of at least .15 or .2 , which tend to exclude interesting cases; or small drops of less than .09, which quickly increase the number of dubious cases that are probably reflections of measurement uncertainty. (There are 941 drops of less than 0.09 points.) Conveniently, a threshold of .09 is the largest magnitude that still includes Russia under Putin, which, as noted above, seems important to include.

Only 54 country-years in 23 countries experienced a decline in liberal democracy this large within five years of having sustained minimal electoral democracy for at least eight years. Figure 1 traces the liberal democracy trends for the eleven countries in this group that had more than one year of sufficient, qualifying decline, which are denoted by red dots. Cases with just one year are listed at the lower-right corner of the figure. Here, with apologies to historians, are thumbnail descriptions of each case, in chronological order.

Argentina 1930: The Radical governments of Hipólito Yrigoyen in the 1920s were increasingly disrupted by anarchist terrorism and street fighting between proto-fascists and anarchists. A coup in 1930, the beginning of the Depression, inaugurated the "Infamous Decade," marked by executions of leftists, exclusion of Radicals from politics, and a series of fraudulent elections.

Germany 1933: In a Depression-era environment of violent polarization, the NSDAP won a plurality of seats in two 1932 Bundestag elections, leading President von Hindenburg to name its leader, Adolph Hitler, Chancellor in January 1933. The Nazis immediately began massive violent persecution of Communists, Socialists, and the Centre Party and domination of the media and civil society organizations. A new, unfair election was held in March 1933, and then the parliament was dissolved and elections were suspended. 


\section{Figure 1}
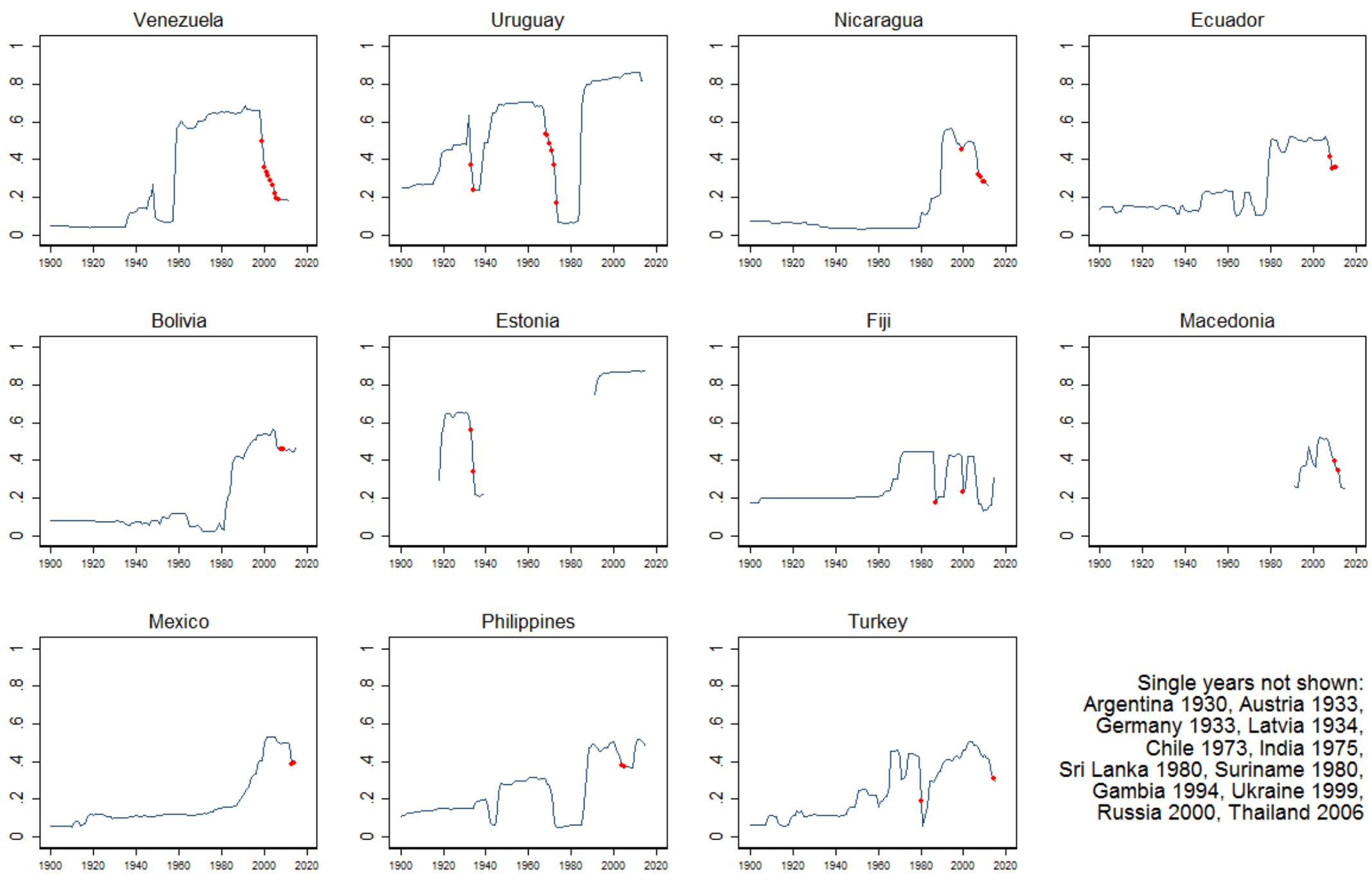

Single years not shown: Argentina 1930, Austria 1933 , Germany 1933, Latvia 1934 ,

Chile 1973, India 1975,

Sri Lanka 1980, Suriname 1980 ,

Gambia 1994, Ukraine 1999,

Russia 2000, Thailand 2006 
Austria 1933: In the interwar context of the Depression, paramilitary violence between socialists and Nazis, and Hitler's rise in Germany, elected Prime Minister Engelbert Dollfuss installed a proclerical fascist regime modeled on Mussolini's, including dissolution of parliament, party bans, and control over the press. A chief aim was to prevent a takeover by the totalitarian Nazi right or Soviet-communist left.

Estonia 1933-34: Both State Elder Jaan Tõnisson and his successor, Konstantin Päts, viewed the opposition Vaps Party as a national socialist movement and were willing to undermine democratic institutions to deny it power. Tõnisson imposed censorship and a state of emergency in 1933. Päts initially reversed these but then led a self-coup in 1934.

Uruguay 1933-1934: During the Great Depression, President Gabriel Terra Leivas disbanded the National Council of Administration, a collegial executive body that was in charge of most domestic policy, so that he could deal with the economic crisis without obstruction. $\mathrm{He}$ also temporarily closed the legislature and imposed some censorship (Alisky 1969, 31 $33)$.

Latvia 1934: During the Depression, and facing an election that his party was likely to lose, Prime Minister Kārlis Ulmanis dissolved parliament and all parties and installed a corporatist authoritarian regime that included a personality cult built around himself.

Uruguay 1968-1973: Two successive presidents, Jorge Pacheco and Juan María Bordaberry, faced with labor unrest and the Tupamaro guerrilla movement, chose to overcome a lack of legislative support by twisting the constitution to rule by administrative fiat. In the process, they repressed leftists and censored the press. In the end, Bordaberry supported the dissolution of the legislature by the military (González and Gillespie 1994, 233-237).

Chile 1973: President Salvador Allende was overthrown by the armed forces (with encouragement from the United States for geopolitical reasons) after his attempt to create a democratic form of socialism that encountered legislative paralysis, a deepening economic crisis, and waves of strikes.

India 1975: After a High Court judge deprived Prime Minister Indira Gandhi her lower-house seat due to violations of election laws, she obtained a state of emergency decree, which enabled her to postpone elections, ban most political parties, arrest opponents, and censor the press for the next two years.

Sri Lanka 1980: The year 1980 is a rather arbitrary point in a gradual decline in liberal democracy from 1969 to 1993, due fundamentally to the civil war between the insurgent Tamil Tigers and increasingly repressive Sinhalese governments. 
Suriname 1980: Just five years after gaining independence from the Netherlands, Suriname experienced two coups led by Sergeant-Major Dési Bouterse, who suspended elections, dissolved parliament, banned parties, censored the press, and ruled as a dictator until 1987.

Turkey 1980: Amid street violence between leftists and rightists, General Kenan Evren led a military coup and imposed martial law.

Fiji 1987 and 2000: A running rivalry between indigenous Fijians and Indo-Fijians fueled intense competition for power. In 1987, Col. Sitiveni Rabuka led two coups, first to remove a newly-elected Indo-Fijian government and then to change the constitution. The 2000 coup was also led by indigenous Fijians against an Indo-Fijian government.

Gambia 1994: Lieutenant Yahya Jammeh overthrew elected President Dawda Jawara in a bloodless coup. Jammeh banned all political activity, imposed some controls on the press, and rewrote the constitution, but then held new elections two years later, which he won. He remained in power until he was removed by popular protests after losing the election of 2016.

Ukraine 1999: Leonid Kuchma was elected to a second term as President in 1999. This election was considered less fair than the 1994 election. As President, Kuchma was pro-Russia and cracked down on opposition press. He was also accused of ordering the murder of at least one journalist.

Venezuela 1999-2007: President Hugo Chávez Frías, repeatedly elected, took advantage of the 1999 Constituent Assembly to rewrite the constitution and the electoral law, dissolve the congress and supreme court, and fire hundreds of judges. New governmental bodies were dominated by Chávez supporters. He also gradually intimidated the media, weakened labor unions, and jailed or exiled opposition leaders accused of supporting a failed coup attempt.

Nicaragua 1999 and 2007-2010: Both Arnoldo Alemán (1999) and Daniel Ortega (2007-2010 and beyond), once rivals and later mysteriously allies, worked to undermine judicial independence, allegedly to protect corrupt officials. Ortega, a Sandinista leader and international ally of Hugo Chávez, was accused of election fraud in 2008 that favored his party at the expense of the opposition.

Russia 2000: Vladimir Putin has been Prime Minister or President since 2000, and executive powers have followed the man, not the office. Although he kept legislatures open and continued to enjoy election victories and high approval ratings, elections soon became much less than fair. He has used state and state-aligned media to flood public 
information with propaganda, has jailed or exiled potential rivals from business and government, and selectively harasses protesters and other dissidents. In 2005, he ended all elections of regional governments.

Philippines 2004-2005: Gloria Macapagal-Arroyo (2001-2010) came into office under a cloud. She was the Vice President to President Joseph Estrada, who resigned under the threat of impeachment for corruption. Arroyo herself faced down impeachment attempts motivated by charges of fraud in the 2004 presidential election, and she was accused of corruption as well. In 2006 she declared a state of emergency to prevent a rumored coup attempt.

Thailand 2006: The 2001-2006 presidency of Thaksin Shinawatra polarized Thai society. He enjoyed majority support from the rural areas for his redistributive policies, but faced frequent large protests in urban Bangkok, where a more educated public tended to consider him a demagogue. The opposition tried unsuccessfully to remove him with protests, an impeachment bill for corruption, and pleading for royal intervention. Some opposition figures boycotted the 2006 parliamentary elections, leading to a constitutional crisis and a military coup.

Bolivia 2008-2009: President Evo Morales (2006-present), another Chávez ally, also summoned a constituent assembly (2006) that produced a new constitution. He faced sometimesviolent opposition from conservative secessionist elites in the east and later from his own indigenous base, but maintained high approval ratings and harmed liberal democracy less than his international allies.

Ecuador 2008-2011: President Rafael Correa (first term; he stayed in office until 2017) followed the Chávez playbook by summoning a constituent assembly that dissolved congress in 2008. He then used control of the electoral tribunal to purge opponents from the congress. He also threatened opposition media and set up several pro-government media outlets.

Macedonia 2010 \& 2012: Prime Minister Nikola Gruevski’s governments (2006-2016) exerted strong pressure on the media, closing several outlets and provoking self-censorship. The courts and civil society organizations were heavily politicized. Some state resources were used to benefit the governing coalition in elections (Freedom House 2012).

Mexico 2013-2014: The presidency of Enrique Peña Nieto (2012-present) marks the first government by the formerly authoritarian Institutional Revolutionary Party (PRI) since the transition to democracy in 2000. Claims of media manipulation and excessively 
partisan election management have grown, while problems with corruption and drugrelated violence continue.

Turkey 2014: In 2014, Recep Tayyip Erdoğan became President after having been Prime Minister since 2003, and he began to augment the powers of the presidency to suit his ambitions. The presidency had traditionally been non-partisan, but as President he remained openly supportive of his Justice and Development Party. He also intimidated the press, politicized the courts, and worked relentlessly to marginalize the Kurdish PKK and an alleged "parallel state" conspiracy led by the cleric Fethullah Gülen.

All of these cases experienced erosions in liberal democracy, yet there are clear differences among them. Some ended in military coups, others in fascist dictatorships, and others led to subtler constraints on the courts, the media, civil society, or the party system and elections. Some were violent, others peaceful. This analysis using the liberal democracy index tells us only which cases declined, by how much, on this index; it does not tell us which aspects of liberal democracy declined. Did they all decline together? Did some aspects worsen while others did not? Did all these cases follow the same pattern of decline, perhaps to different degrees?

\section{Disaggregating the Two Components of Liberal Democracy}

Fortunately, V-Dem data enable us to drill down, teasing apart which aspects declined and which did not. As a first cut, we can distinguish between the two indices used to construct the Liberal Democracy Index: the Electoral Democracy Index and the Liberal Component Index. Figure 2 overlays the relationship between these two measures for three different samples. The gray dots represent the entire sample: all 16,259 country-years that have scores on both indices. They are related: a high degree of electoral democracy is nearly sufficient for a high degree of liberalism, and a high degree of liberalism is practically necessary for a high degree of democracy. But at low levels of liberalism and electoral democracy, there is not much of a relationship. The black dots represent the cases meeting the scope conditions of having had electoral democracy for at least eight years, while keeping elections on course and not succumbing to foreign invasion. These cases conform to the same pattern as the full sample, which can be seen from their nearly indistinguishable lowess fit lines (in gray and black to match their respective samples).

The third sample, in red, follows a slightly different pattern, however. These are the cases that meet the scope conditions and also declined significantly in the subsequent five years. The 
lowess fit line is the same for the highest and lowest cases, but in the intermediate range, approximately $0.5<$ electoral democracy $<0.75$, the red line dips below the other two. In this range, therefore, cases tend to decline more on the liberal component than they do on electoral democracy. They are erosions of horizontal accountability. The cases that most are most responsible for this dip are labeled, and it is rather startling to see that they are all Latin American cases, and not just Latin American, but also governments that were allied with the Chávez government in Venezuela: Correa in Ecuador, Ortega in Nicaragua, and Morales in Bolivia, with Venezuela itself being the most influential case. This small cluster of cases clearly constitutes a distinct erosion path in which a government undermines horizontal accountability to a greater degree than it does electoral democracy. Why this pattern is found in these four countries, Figure 2 does not reveal; but it suggests that there is truth to anecdotes I have heard about the Chávez government sending teams of consultants out to other left-of-center governments in the region to spread the idea of consolidating political power before launching economic and social restructuring of the economy.

Figure 2: Disaggregating Two Components of Liberal Democracy

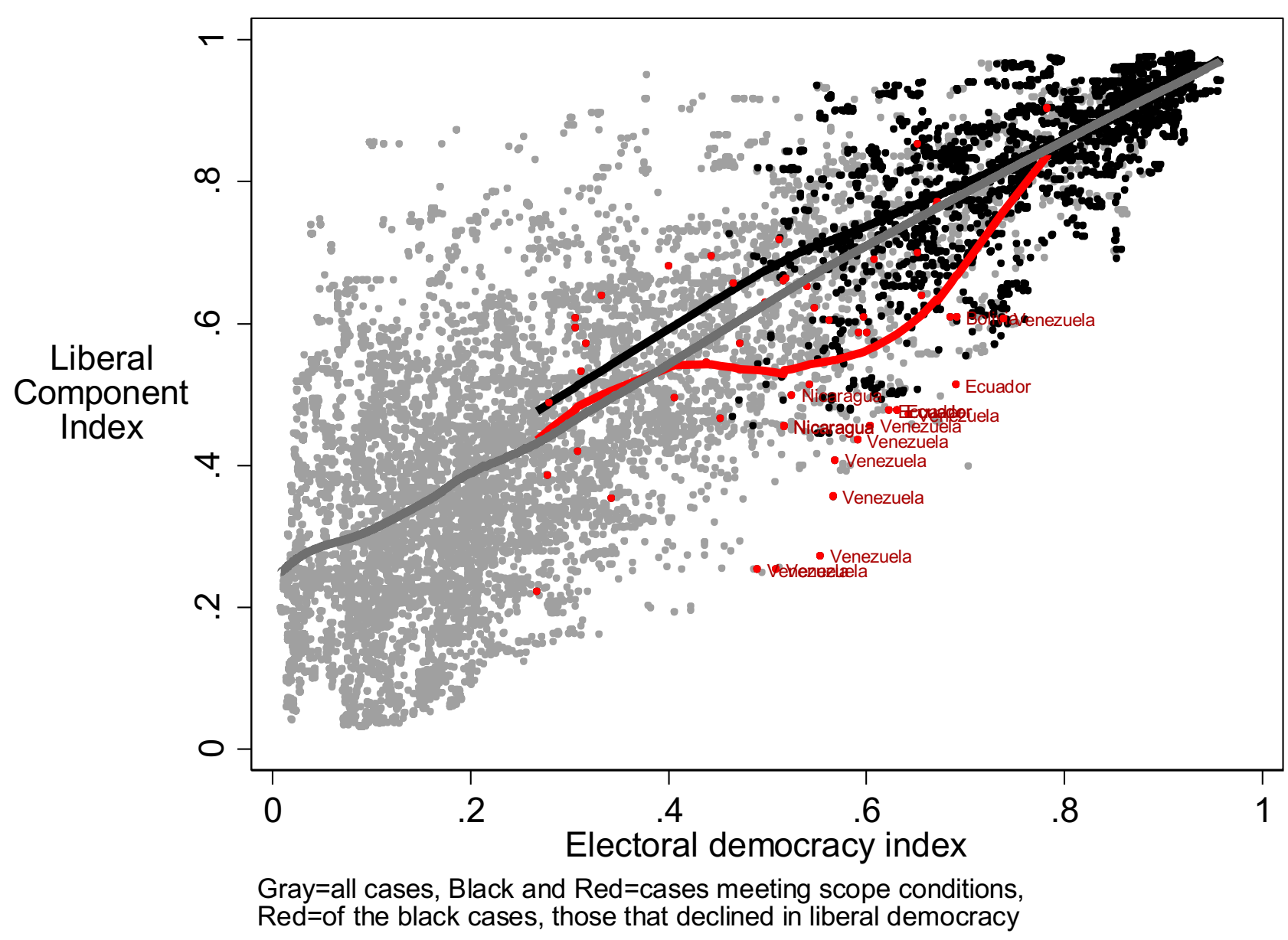




\section{Disaggregating to Eight Sub-Components of Liberal Democracy}

We need not stop disaggregating at the two components: we can drill down further to the eight sub-components of liberal democracy, and also introduce the Deliberative Component Index into the analysis. The benefits of analyzing sub-components are that they preserve more of the variance measured by the most specific indicators, adding more distinct information to the analysis; it improves the qualitative clarity of the interpretations of the relationship, since we can distinguish a change in one subcomponent from a change in any other subcomponent; each subcomponent is less diluted with variance on irrelevant concepts; and disaggregating affords a better opportunity to analyze different dimensions in the data. In other words, disaggregating makes it more like that we will find distinct paths (if they exist) and that we will be able to interpret what those paths mean.

The eight sub-components that are conceptually relevant are Clean elections, Freedom of expression, Media pluralism, Civil liberties, Freedom of association, Judicial constraints on the executive, Legislative constraints on the executive, and deliberation. The structure and meaning of each of these components are fully described in the appendix. Using multiple components makes it possible to expand the sample to include cases that dropped on any of the eight, which is a lower threshold than dropping on enough of the eight to force a sufficiently large drop on a more aggregated index. There are 2,071 country-years that decline at all on any component and 214 cases that decline by at least 0.09 .

The expanded sample gives us enough cases to analyze the dimensionality of declines in components for cases that meet the scope conditions. Table 1 reports an exploratory factor analysis of the 201 cases with complete data on all eight components, which finds that there are two significant factors. ${ }^{6}$ Each factor represents a distinct dimension in the data, suggesting two different paths of erosion in democracy. The first dimension is most closely aligned with freedom of expression and the existence of alternative sources of information, but it is also strongly correlated with the deliberative component, freedom of association, and civil liberties (the "Equality before the law and individual liberty index"). We can call this a "rights and freedoms" dimension: countries that decline on this dimension primarily lose rights and freedoms. Two of the three components loading on the second dimension are the familiar judicial and legislative constraints on the executive, which constitute horizontal accountability.

\footnotetext{
${ }^{6}$ EFA identifies two significant factors whether the threshold is $.09, .1, .2$, or .3, although the Clean elections component loads more heavily on an insignificant third factor when a threshold of .2 or .3 reduces the sample size.
} 
But the Clean elections component also loads on this factor, which suggests that some vertical accountability is included as well, although the two horizontal components contribute more than twice as much to this dimension as vertical accountability does. We can therefore call this an "accountability" dimension: countries that decline on this dimension primarily suffer losses of accountability, especially horizontal accountability.

Table 1: Exploratory Factor Analysis of Components

\section{Component}

Freedom of expression
Alternative sources of information
Deliberative component
Freedom of association
Civil liberties
Judicial constraints on the executive
Legislative constraints on the
executive
Clean elections

Eigenvalue

Proportion of variance explained

\section{Factor1 Factor2 Uniqueness}

\begin{tabular}{|c|c|c|}
\hline 0.967 & 0.071 & 0.059 \\
\hline 0.924 & -0.010 & 0.125 \\
\hline 0.681 & 0.031 & 0.495 \\
\hline 0.659 & 0.055 & 0.449 \\
\hline 0.603 & 0.272 & 0.370 \\
\hline 0.228 & 0.632 & 0.542 \\
\hline 0.357 & 0.602 & 0.501 \\
\hline 0.181 & 0.562 & 0.567 \\
\hline 3.263 & 1.160 & \\
\hline 0.741 & 0.264 & \\
\hline
\end{tabular}


Figure 3 Two Dimensions of Decline

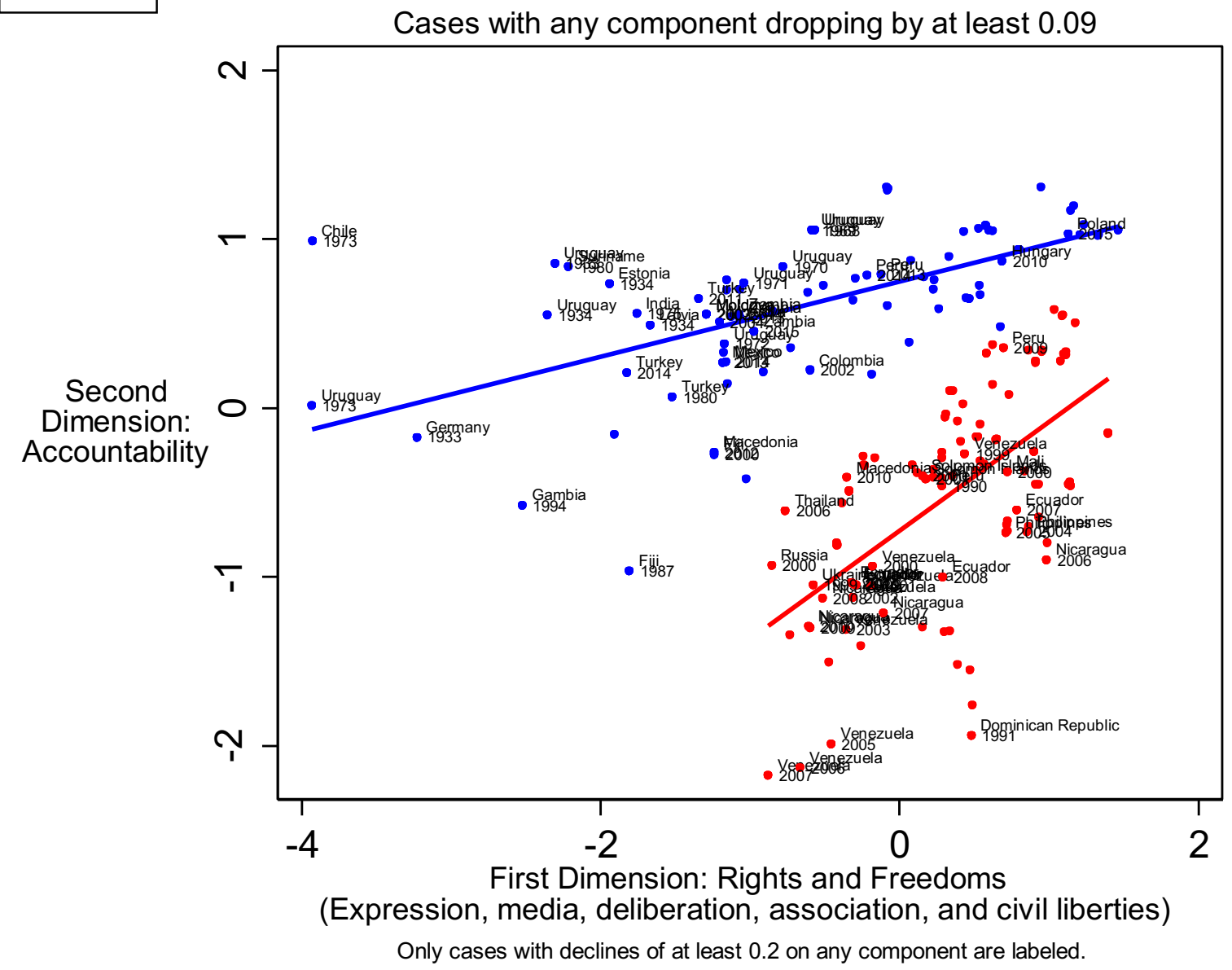

Figure 3 plots the factor scores for these two dimensions. All 201 cases are plotted, but only those with the largest drops in any component are labeled so that most of the labels are legible. There is clearly more than one dimension, and in fact, the cases appear to be clustered along two lines: one line tracing a path on which rights and freedoms erode more than accountability does, and another path on which accountability declines more than rights and freedoms do. I have colored the cases along the first path blue and those along the second path red, and overlaid linear fit lines for each group to accentuate these clusters, but they would be evident without the visual assist. ${ }^{7}$ For example, the region between the two fit lines is more sparsely populated.

Many of the same cases that eroded on liberal democracy also appear in this disaggregated analysis, only now we can classify them into two different types of erosion. Among the most eroded cases on the rights and freedoms dimension are the previously listed cases of

\footnotetext{
${ }^{7}$ Cases are colored red if their scores on the second factor are less than 65 percent of their scores on the first factor. This rubric efficiently separates the two clusters. The fit lines are estimated separately for these two clusters.
} 
Uruguay 1968-1973 (Pacheco and Bordaberry), Chile 1973 (Allende to Pinochet), Germany 1933 (Hitler), Gambia 1994 (Jawara to Jammeh), Uruguay 1933-34 (Terra), Suriname 1980 (Bouterse), Estonia 1933-34 (Tõnisson to Päts), Turkey 2005-14 (Erdoğan), Fiji 1987 and 2000 (Rabuka), India 1974-75 (Gandhi), Latvia 1934 (Ulmanis), Turkey 1980 (Evren), Macedonia 2012 (Gruevski), Mexico 2013-14 (Peña Nieto), Sri Lanka 2005, Austria 1933 (Dollfuss), and Argentina 1930 (Uriburu). However, this more fine-grained analysis also lists some additional cases of erosion on the first dimension, including Honduras 2009 (Micheletti), Moldova 2001-06 (Tarlev), Zambia 2011-15 (Kaunda), Colombia 2002-03 (Uribe), United States 1942 (Roosevelt), Peru 2013-14 (Humala), Finland 1930-32, and Trinidad and Tobago 1964 (Williams). ${ }^{8}$

Similarly, many of the cases that eroded on liberal democracy can be classified as instances of erosion on the accountability dimension. Among the most-eroded cases are the previously listed cases Russia 2000 (Putin), Bolivia 2007-10 (Morales), Philippines 2002-08 (Arroyo), Thailand 2006 (Thaksin), Venezuela 1999-2007 (Chávez), Nicaragua 1998-99 (Alemán), Nicaragua 2007-11 (Ortega), Ecuador 2007-12 (Correa), Sri Lanka 1971-74 (Bandaranaike) and 1978-86 (Premadasa), and Macedonia 2010 (Gruevski). However, this analysis turns up even more additional cases: Mali 2000 (Sidibé) and 2003-05 (Touré), Peru 1990-91 (Fujimori), Senegal 2001-04 (Wade), Argentina 1992-93 (Menem), Benin 2000-02 (Kérékou), Burkina Faso 2010-12 (Compaoré), Indonesia 2010-12 (Yudhoyono), Nicaragua 2006 (Bolaños), East Timor 2015 (Ruak), Ecuador 1987 (Febres-Cordero) and 1988 (Borja) and 2002 (Noboa) and 2004 (Gutiérrez), Ukraine 1999 (Yushchenko), Dominican Republic 1987-91 (Balaguer) and 2007 (Fernández), Madagascar 2002 (Sylla), Guyana 2001-04 (Burnham), Paraguay 2014-15 (Cartes), and the Solomon Islands 1999-2001. In this group, the erosion of accountability no longer looks like an exclusively Chavista or even Latin American phenomenon.

Both types of erosion have been more common since 2000, but this is mostly because, before the Third Wave of democratization, far fewer countries were democratic and stable enough to be in a position to backslide.

\section{Further Disaggregation, to Indicators}

It is possible to disaggregate further and analyze the relationships among the 29 most specific indicators that constitute the eight components above. Some additional potentially useful information could be uncovered this way, as the components do not explain a quarter of the variance measured by the specific indicators. However, an exploratory factor analysis of all of the

\footnotetext{
${ }^{8}$ These, and the cases in the next paragraph, are those with below-average scores on the corresponding factor.
} 
specific indicators together is not revealing. Most of the variables load on a first factor that accounts for only about 60 percent of the variance, and the rest load on two or three factors that are not robust. The nature of the additional factors depends on the threshold of change one uses: sometimes they measure freedom of discussion, sometimes judicial independence, and sometimes both. Analyzing the dimensions of the components, as in the previous section, yields a clearer, more interpretable picture of the relationships in the data.

A better way to make use of the specific indicators is to examine changes in each variable within countries, and then group together countries that experienced drops in the same variables. This kind of analysis can reveal the extent to which different countries have eroded in the same specific ways. It is hard not to miss the forest for the trees in such an analysis, as Figure 4 demonstrates. This figure is a network graph that maps the relationships between the indicators and the countries. Countries are depicted by brown nodes, indicators by blue or red nodes. The blue nodes are for indicators that more relevant for the rights and freedoms dimension and the red nodes are for the horizontal accountability indicators. A country is connected to an indicator in the figure whenever it experienced a drop of about one standard deviation (1.5 for these indicators) in a year that met the scope conditions. 'The widths of the connecting lines are proportional to the number of years of decline, as different countries declined in different years, and in fact the same country often declined in different years on different indicators. The years of decline for each country-indicator combination are labeled on the lines. The lines are also colored a lighter shade of the indicators to which they connect so that it is easier to see which countries declined on which dimensions of erosion.

Figure 4 is admittedly unfamiliar, complex, and confusing. Nevertheless, several conclusions can be gleaned from this mapping after some patient study. First, no two countries have eroded in the same way. Each country has a different mix of drops on different indicators (and of course to different degrees, which are not represented here). Any similarities are better appreciated in Figure 3, which is based on component indices that combine several specific indicators. We can say, for example, that Poland, Ghana, and Paraguay all recently declined in the quality of political discourse (the deliberative component); but Ghana and Paraguay declined only on the Reasoned justification indicator, while Poland also declined on the Range of consultation and Respect for counterarguments.

\footnotetext{
9 Different drop thresholds would modify the set of countries and indicators that need to be included in the figure and how they are mapped together. However, many of the same countries and indicators would still be there, related in similar ways. The basic conclusions from this analysis would not be substantially altered. I chose a threshold that selects the maximum number of nodes that I could legibly fit on such a chart.
} 


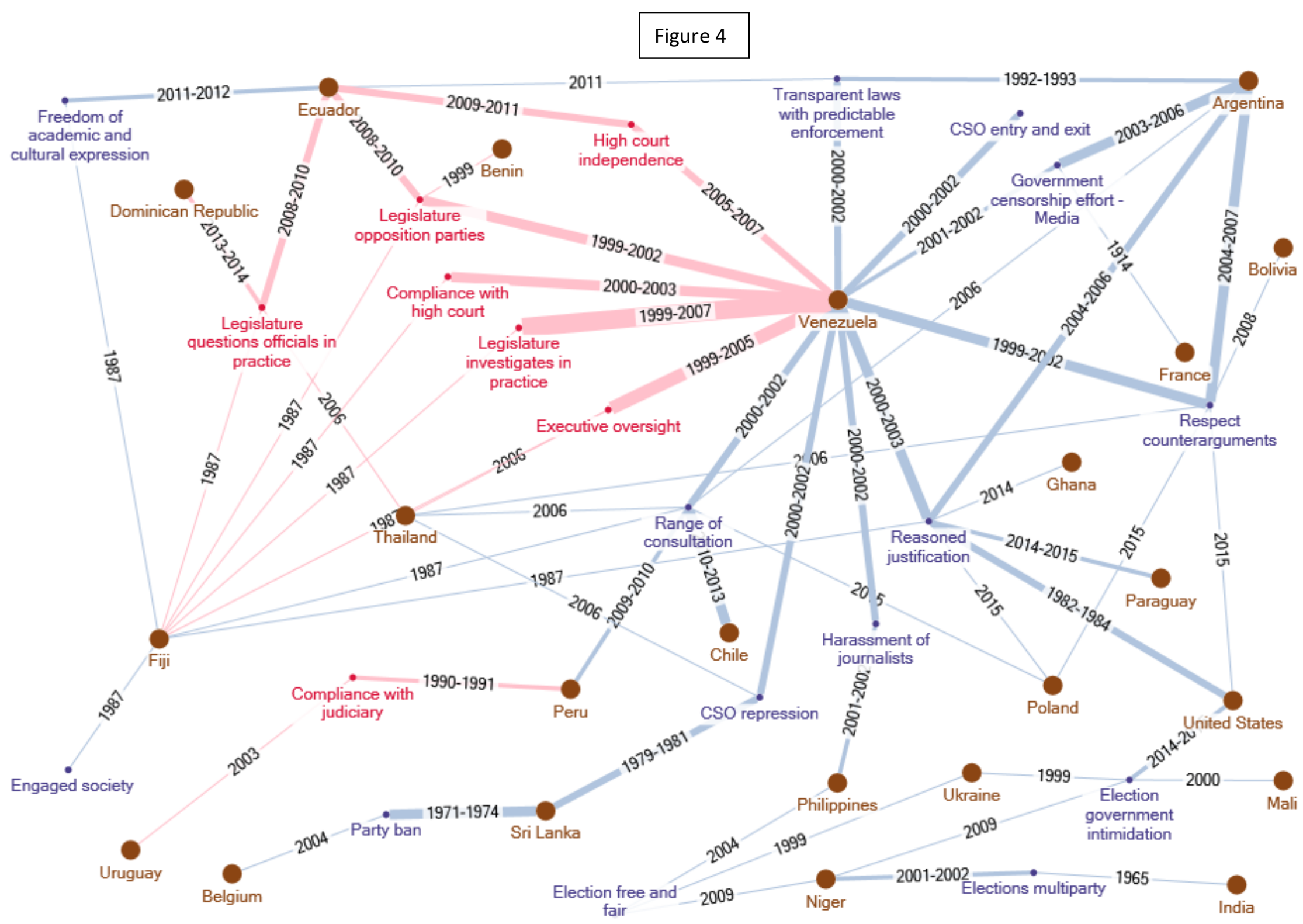


Second, Venezuela stands out as the country where democracy, especially on the accountability dimension, has eroded the most, in the largest number of ways, and over the longest span of time. It is hard to have a discussion of unexpected erosion or backsliding of democracy without mentioning Venezuela: it is the ideal-type. For the same reason, it is far from the most typical case. As Figure 4 shows, there were declines on 13 specific indicators in Venezuela. The next-closest case is Fiji, which declined on nine, followed by Argentina, Thailand, and Ecuador, which declined on five. Varying the threshold for a "decline" would alter these counts but not the exceptional nature of the erosion of democracy in Venezuela. The depth of Venezuela's decline is also plain to see in figures 1-3. Other cases share some family resemblances to the Venezuelan ideal-type, especially Ecuador, Argentina, Thailand (and maybe Fiji 1987, but that is better classified as a military coup, even though an election came soon after). But Niger, Ukraine, India, Belgium, the Dominican Republic, Mali, and Uruguay have no declining indicators in common with Venezuela for the years declining by -1.5 or more. Third, some of the contemporary cases that loom large in discussion of erosions did not surpass this threshold: Russia under Putin, Nicaragua under Ortega, Bolivia under Morales (except for one indicator). If a lower threshold, a decline of at least 1 point on any indicator, is used, then Russia qualifies for freedom of discussion for women and freedom of academic and cultural discussion. Bolivia also qualifies for respecting counterarguments, range of consultation, election intimidation, executive oversight, and EMB autonomy. Turkey would qualify as having eroded on the rights and freedoms dimension. Nicaragua is mostly invariant, but it would qualify on the multiparty elections indicator. Surprisingly, Hungary and Macedonia do not qualify on either dimension even with a -1 threshold. This may be an artifact of version 6.2 of the data; I expect they will be included when using version 7 .

\section{Consequences}

Do these erosion paths matter? A simple preliminary analysis suggests that there is a significantly increased risk that the electoral regime in a year following erosion, but this relationship seems to be driven almost entirely by Venezuela. However, as Table 2 shows, there is much stronger relationship between the accountability dimension and corruption, even in very rigorous estimates (lagged DV, lagged accountability, controlling for the first dimension and logged per capita GDP, clustered by country, with fixed effects). Interestingly, there is no significant relationship between the rights and freedoms dimension and corruption. The regimes with 
eroded accountability are among the most corrupt countries in the world: Russia, Venezuela, El Salvador, Bangladesh, Thailand, Dominican Republic, and Guyana, for example. One wonders whether corruption is the motivation for limiting accountability in the first place; or whether the lack of horizontal accountability just permits the growth of corruption, which then makes it harder to restore accountability. It appears to be more the latter, as in a similarly specified model, lagged corruption does not explain accountability.

Table 2: Impact of Accountability on Corruption

\begin{tabular}{|l|l|l|l|l|}
\hline Corruption_t & Coef. & Std.Err. & $\mathrm{t}$ & $\mathrm{p}$ \\
\hline Corruption_t-1 & 0.938 & 0.017 & 55.3 & 0 \\
\hline Rights \& freedoms index_t-1 & -0.0003 & 0.002 & -0.16 & 0.877 \\
\hline Accountability index_t-1 & -0.0096 & 0.003 & -3.40 & 0.001 \\
\hline ln(GDP per capita) & 0.0015 & 0.001 & 1.72 & 0.088 \\
\hline Intercept & 0.0101 & 0.007 & 1.44 & 0.152 \\
\hline sigma_u & 0.0187 & & & \\
\hline sigma_e & 0.0121 & & & \\
\hline rho & 0.7035 & & & \\
\hline
\end{tabular}

$\mathrm{N}=2,421$ in 84 countries. Fixed-effects regression with errors clustered by countries.

R-sq:

within $\quad 0.895$

between $\quad 0.998$

overall 0.996 


\section{References}

Alisky, Marvin. 1969. Uruguay: A Contemporary Survey. New York: Praeger.

O’Donnell, Guillermo.1994. "Delegative Democracy," Journal of Democracy, vol. 5, no. 1 (January): $55-69$

V-Dem Codebook: Coppedge, Michael, John Gerring, Staffan I. Lindberg, Svend-Erik Skaaning, Jan Teorell, with David Altman, Michael Bernhard, M. Steven Fish, Adam Glynn, Allen Hicken, Carl Henrik Knutsen, Kelly McMann, Pamela Paxton, Daniel Pemstein, Jeffrey Staton, Rachel Sigman, Brigitte Zimmerman, Frida Andersson, Valeriya Mechkova, and Farhad Miri. 2015. "V-Dem Codebook v6." Varieties of Democracy (V-Dem) Project.

Freedom House. 2012. Nations in Transit: Macedonia. https://freedomhouse.org/report/nationstransit/2012/macedonia, accessed April 14, 2017.

González, Luis Eduardo and Charles Gillespie, "Presidentialism and Democratic Stability in Uruguay," in Juan J. Linz and Arturo Valenzuela, eds., The Failure of Presidential Democracy, pp. 225-252. Baltimore: The Johns Hopkins University Press, 1994.

Pemstein, Daniel, Eitan Tzelgov and Yi-ting Wang. 2015. "Evaluating and Improving Item Response Theory Models for Cross-National Expert Surveys." University of Gothenburg, Varieties of Democracy Institute: Working Paper No. 1. March 2015

Michael Coppedge, Staffan I. Lindberg, Svend-Erik Skaaning, and Jan Teorell. 2016. "Measuring High Level Democratic Principles using the V-Dem Data," International Political Science Review 37:5 (November): 580-593. 


\section{Appendix}

\section{Indices and Indicators Used in This Analysis}

Below are the definitions of V-Dem's Liberal Democracy Index and the Deliberative Component Index. Indented underneath them are definitions of their components and the subcomponents and indicators that are used in this paper. The complete definitions of the indicators would include the ordinal category descriptions. They are omitted here but can be found in the codebook (Coppedge et al. 2016, which is the source for this appendix) or online https://v-dem.net. Many subcomponents and indicators are used in the official indices that are not used in this paper because I do not consider them relevant for defining or measuring recent erosions of democracy. The omitted variables are listed below without definitions.

\section{Liberal Democracy Index (v2x_libdem)}

The liberal principle of democracy emphasizes the importance of protecting individual and minority rights against the tyranny of the state and the tyranny of the majority. The liberal model takes a "negative" view of political power insofar as it judges the quality of democracy by the limits placed on government. This is achieved by constitutionally protected civil liberties, strong rule of law, an independent judiciary, and effective checks and balances that, together, limit the exercise of executive power. To make this a measure of liberal democracy, the index also takes the level of electoral democracy into account.

Electoral Democracy Index (v2x_polyarchy)

Clean elections index (v2xel_frefair)

To what extent are elections free and fair? Clarifications: Free and fair connotes an absence of registration fraud, systematic irregularities, government intimidation of the opposition, vote buying, and election violence.

EMB autonomy (v2elembaut)

Does the Election Management Body (EMB) have autonomy from government to apply election laws and administrative rules impartially in national elections?

Election free and fair (v2elfrfair) 
Taking all aspects of the pre-election period, election day, and the postelection process into account, would you consider this national election to be free and fair?

Election government intimidation (v2elintim)

In this national election, were opposition candidates/parties/campaign workers subjected to repression, intimidation, violence, or harassment by the government, the ruling party, or their agents?

Elections multiparty (v2elmulpar)

Was this national election multiparty?

Omitted from this analysis: Elected executive index (de jure) (composed of 12 indicators), EMB capacity, Election voter registry, Election vote buying, Election other voting irregularities, Election other electoral violence.

Freedom of expression index (v2x_freexp $)^{10}$

To what extent does government respect press \& media freedom, the freedom of ordinary people to discuss political matters at home and in the public sphere, as well as the freedom of academic and cultural expression?

Freedom of discussion for men (v2cldiscm)

Are men able to openly discuss political issues in private homes and in public spaces?

Freedom of discussion for women (v2cldiscw)

Are women able to openly discuss political issues in private homes and in public spaces?

Freedom of academic and cultural expression (v2clacfree)

Is there academic freedom and freedom of cultural expression related to political issues?

${ }^{10} \mathrm{~V}$-Dem officially uses an expanded freedom of expression index that incorporate the variables in the Alternative sources of information index. I keep these subcomponents separate in this analysis for conceptual clarity, although they are very strongly correlated. 
Alternative sources of information index (v2xme_altinf)

To what extent is the media (a) un-biased in their coverage (or lack of coverage) of the opposition, (b) allowed to be critical of the regime, and (c) representative of a wide array of political perspectives?

Government censorship effort - Media (v2mecenefm)

Does the government directly or indirectly attempt to censor the print or broadcast media?

Harassment of journalists (v2meharjrn)

Are individual journalists harassed - i.e., threatened with libel, arrested, imprisoned, beaten, or killed -- by governmental or powerful nongovernmental actors while engaged in legitimate journalistic activities?

Omitted from analysis: Print/broadcast media critical, Print/broadcast media perspectives, Government censorship effort - Internet, Media selfcensorship, Media bias.

Freedom of association index (v2x_frassoc_thick)

To what extent are parties, including opposition parties, allowed to form and to participate in elections, and to what extent are civil society organizations able to form and to operate freely?

CSO entry and exit (v2cseeorgs)

To what extent does the government achieve control over entry and exit by civil society organizations (CSOs) into public life?

CSO repression (v2csreprss)

Does the government attempt to repress civil society organizations (CSOs)?

Elections multiparty (v2elmulpar)

Was this national election multiparty?

Opposition parties autonomy (v2psoppaut) 
Are opposition parties independent and autonomous of the ruling regime?

Party ban (v2psparban)

Are any parties banned?

Barriers to parties (v2psbars)

How restrictive are the barriers to forming a party?

CSO participatory environment (v2csprtcpt) (Used in indicator-level analysis but not part of the Freedom of association index.)

Which of these best describes the involvement of people in civil society organizations (CSOs)?

Omitted from this analysis: Percent of population with suffrage.

\subsection{Liberal Component Index (v2x_liberal)}

To what extent is the liberal principle of democracy achieved? Clarification: The liberal principle of democracy emphasizes the importance of protecting individual and minority rights against the tyranny of the state and the tyranny of the majority. The liberal model takes a "negative" view of political power insofar as it judges the quality of democracy by the limits placed on government. This is achieved by constitutionally protected civil liberties, strong rule of law, an independent judiciary, and effective checks and balances that, together, limit the exercise of executive power.

Judicial constraints on the executive (v2x_jucon)

To what extent does the executive respect the constitution and comply with court rulings, and to what extent is the judiciary able to act in an independent fashion?

Compliance with judiciary (v2jucomp)

How often would you say the government complies with important decisions by other courts with which it disagrees?

Compliance with high court (v2juhccomp) 
How often would you say the government complies with important decisions of the high court with which it disagrees?

High court independence (v2juhcind)

When the high court in the judicial system is ruling in cases that are salient to the government, how often would you say that it makes decisions that merely reflect government wishes regardless of its sincere view of the legal record?

\section{Lower court independence (v2juncind)}

When judges not on the high court are ruling in cases that are salient to the government, how often would you say that their decisions merely reflect government wishes regardless of their sincere view of the legal record?

Omitted from this analysis: Executive respects constitution.

Legislative constraints on the executive (v2xlg_legcon)

To what extent are the legislature and government agencies (e.g., comptroller general, general prosecutor, or ombudsman) capable of questioning, investigating, and exercising oversight over the executive?

Legislature questions officials in practice (v2lgqstexp)

In practice, does the legislature routinely question executive branch officials?

\section{Executive oversight (v2lgotovst)}

If executive branch officials were engaged in unconstitutional, illegal, or unethical activity, how likely is it that a body other than the legislature, such as a comptroller general, general prosecutor, or ombudsman, would question or investigate them and issue an unfavorable decision or report?

Legislature investigates in practice (v2lginvstp)

If the executive were engaged in unconstitutional, illegal, or unethical activity, how likely is it that a legislative body (perhaps a whole chamber, 
perhaps a committee, whether aligned with government or opposition) would conduct an investigation that would result in a decision or report that is unfavorable to the executive?

Legislature opposition parties (v2lgoppart)

Are opposition parties (those not in the ruling party or coalition) able to exercise oversight and investigatory functions against the wishes of the governing party or coalition?

Equality before the law and individual liberty (v2xcl_rol)

To what extent are laws transparent and rigorously enforced and public administration impartial, and to what extent do citizens enjoy access to justice, secure property rights, freedom from forced labor, freedom of movement, physical integrity rights, and freedom of religion?

Rigorous and impartial public administration (v2clrspct)

Are public officials rigorous and impartial in the performance of their duties?

Transparent laws with predictable enforcement (v2cltrnslw)

Are the laws of the land clear, well-publicized, coherent (consistent with each other), relatively stable from year to year, and enforced in a predictable manner?

Omitted from this analysis: Access to justice for men, Access to justice for women, Property rights for men, Property rights for women, Freedom from torture, Freedom from political killings, Freedom from forced labor for men, Freedom from forced labor for women, Freedom of religion, Freedom of foreign movement, Freedom of domestic movement for men, Freedom of domestic movement for women.

\section{Deliberative Component Index (v2xdl_delib)}

To what extent is the deliberative principle of democracy achieved? Clarification: The deliberative principle of democracy focuses on the process by which decisions are reached in a 
polity. A deliberative process is one in which public reasoning focused on the common good motivates political decisionsas contrasted with emotional appeals, solidary attachments, parochial interests, or coercion. According to this principle, democracy requires more than an aggregation of existing preferences. There should also be respectful dialogue at all levels from preference formation to final decision among informed and competent participants who are open to persuasion. To measure these features of a polity we try to determine the extent to which political elites give public justifications for their positions on matters of public policy, justify their positions in terms of the public good, acknowledge and respect counter-arguments; and how wide the range of consultation is at elite levels.

Reasoned justification (v2dlreason)

When important policy changes are being considered, i.e. before a decision has been made, to what extent do political elites give public and reasoned justifications for their positions?

Respect counterarguments (v2dlcountr)

When important policy changes are being considered, to what extent do political elites acknowledge and respect counterarguments?

Range of consultation (v2dlconslt)

When important policy changes are being considered, how wide is the range of consultation at elite levels?

Engaged society (v2dlengage)

When important policy changes are being considered, how wide and how independent are public deliberations?

Omitted from this analysis: Common good 